\title{
Dependence of Academic Performance on English Speaking Anxiety in Academic Programs of English Medium Instructional Context
}

\author{
Rafaquat Ali $^{\text {a }}$, Bushra Shoukat ${ }^{\text {b }}$, Ali Ahmad Kharal ${ }^{\text {c }}$ \\ ${ }^{a}$ Assistant Professor, Department of Education, Bahawalnagar Campus, Bahawalnagar, The Islamia \\ University of Bahawalpur, Pakistan \\ Email: rafaquatiub@yahoo.com \\ ${ }^{\mathrm{b}}$ Assistant Professor, Department of English, Bahawalnagar Campus, Bahawalnagar, The Islamia \\ University of Bahawalpur, Pakistan \\ Email: bushra.shoukat@iub.edu.pk \\ ${ }^{c}$ Principal, Islamabad College for Boys, Sector: G-6/3, Islamabad, Pakistan \\ Email: dralikharal@gmail.com
}

\begin{tabular}{l} 
ARTICLE DETAILS \\
\hline History: \\
Accepted 17 December 2021 \\
Available Online December 2021
\end{tabular}

\section{Keywords:}

English Medium Instruction, Communication Apprehension, Test Anxiety, Anticipated Anxious behaviour in speaking English, Comfort in speaking English, Science Students, Academic Performance, Pakistan

JEL Classification:

P36, I21

DOI: $10.47067 /$ reads.v7i4.410

\begin{abstract}
Most countries in the world have adopted English Medium instruction in universities. The increasing global trend of the English language as the medium of instruction has made researchers focus on students' adjustment and performance in English medium instructional contexts. One key issue highlighted in English medium instruction is English speaking anxiety. The literature has pointed out that English language speaking anxiety among students has a dependency on their personal and interpersonal worries and the context of learning. Pakistan is also a country that has adopted English medium instruction at different levels of education. Therefore, the current study probed the dependencies of English language speaking anxiety on students' academic programs and how these anxieties impact students' academic performance in Pakistan. The survey study design consisted of convenience or accidental sampling. The structural equation modeling helped researchers infer the significance of academic programs' impact on academic performance, the effect of language anxiety dimensions on academic performance, and the impact of academic programs on academic performance via Englishspeaking anxieties. The academic departments significantly impact students' academic performance directly and indirectly through language-speaking anxieties.
\end{abstract}

(C) 2021 The authors. Published by SPCRD Global Publishing. This is an open access article under the Creative Commons Attribution-

NonCommercial 4.0

Corresponding author's email address: rafaquatiub@yahoo.com

\section{Introduction}

In an era of modern times, the English language has occupied a pivotal position in the league of international languages and has become a tool of globalization (Schneider, 2014). This world language 


\section{Review of Economics and Development Studies, Vol. 7 (4) 2021, 501 - 514}

is not limited to only being used for translation communication, but it is now the language of business, diplomacy, education, arts, sports, and tourism (Schneider, 2014). The English language is successful enough to compete with national languages in different countries such as Japan, Germany, Spain, and France (Shohamy, 2014). The educational policies of various nations have introduced English as a compulsory subject at the primary level (Nunan, 2003), and most of the countries have opted for the English medium of instruction and examination at higher education level (Foyewa, 2015). English has been recognized as the language of science and research (Gordin, 2015), and more than 98\% of international scientific research is published in English (Ramírez-Castañeda, 2020).

This mounting importance of English in an era of globalization has highlighted different issues related to English language learning in non-native English-speaking countries. In teaching English, whether as a foreign language, or a mainstream subject, the four skill areas are focused on; reading, writing, speaking, and listening (Hinkel, 2006). However, English speaking skills depend on several other vital skills: content, discourse, information structuring, and the sound system (Nunan, 2003). These sub-skills put students under stress while speaking and anticipating English speaking situations, and students might undergo anxiety. Public speaking anxiety is considered a panic of delivering a speech or talk in public or a classroom because the speaker worries about negative feedback and expects humiliation from others (American Psychological Association, 2020). At the same time, the field has turned into English language anxiety, and the researchers now see this as a global phenomenon (Nunan, 2003). From a psychological perspective, these are undesired cognitive and physiological reactions to a social and public speaking environment that end in difficulties in speaking effectively (Fremouw \& Breitenstein, 1990). In other words, language anxiety is the condition of uneasiness felt by the learners in situations that involve the use of the English language, such as the classroom or formal and informal discussions (Gardner \& MacIntyre, 1993). Although anxiety is mostly prevailing among students, it moderately impacts routine life (Rapee et al., 2009).

Often, academicians use communication apprehension and audience anxiety in place of speech anxiety (Fremouw \& Breitenstein, 1990). However, it is a distinctive variable in foreign language learning, and it has unique ramifications because students often think that they do not have the mental ability to learn a foreign language, and they feel that they are not capable of learning this language (Horwitz et al., 1986). Students who suffer from English speaking anxiety avoid potential communication situations to reduce speaking stress (Pappamihiel, 2002). Ultimately, the probability is that this will negatively impact students' academic performance (Aida, 1994). Such students might develop negative beliefs about themselves. For example, they believe that they lack ability, have low intelligence, and are naturally not capable of learning this language (Horwitz et al., 1986). This higher language speech anxiety reduces their internal motivation to learn, and they become anxious during learning and fail to communicate their learning and feelings (Young, 1991). It damages their interpersonal relationships, self-reliance, self-esteem, and consequently, they become stressed and depressed (D'Esposito et al., 2011).

Although personal and interpersonal worries play a critical role in developing language speech anxiety, students' language learning beliefs, teacher-student interactions, classroom environment, and students' language backgrounds also play a prominent role in English speech anxiety (Young, 1991). This language anxiety has a more adverse impact at the university level because teacher-student dialogues and discussions are integral to higher education. Therefore, students' unwillingness and inabilities to communicate hinder their effective communication with teachers at the university level; consequently, they have to suffer academically (Boohar \& Seiler, 1982). Furthermore, those students' academic performance is adversely affected who study subjects that have laboratory work or fieldwork 


\section{Review of Economics and Development Studies, Vol. 7 (4) 2021, 501 - 514}

as part of their educational activities (Miller \& Edmunds, 1992; Seiler et al., 1978). Furthermore, this anxiety is more heightened in small group classes because there is a possibility of frequent teacherstudent communication and dialogue (McCroskey, 1977).

\section{Conceptual Framework}

The students' speech anxiety impedes their learning, and they develop a variety of undesired psychological and mental health issues such as stress, depression, low self-esteem (D'Esposito et al., 2011; Young, 1991), which might be even more harmful to the students not even from the educational perspective but also for overall general health and living (Hughes et al., 2008). Therefore, it is essential to identify English speaking anxiety levels in students. In the ever-increasing importance of the English language in the globalization era, different efforts are underway to understand nature, develop measures, and ascertain the impacts of English speech anxiety on students learning. However, there are various measures, definitions, alternative terms, and construct labels such as communication apprehension, public speaking anxiety, and language anxiety or English speech anxiety (Young, 1991). Yaikhong and Usaha (2012) combined all these measures and proposed an English speech anxiety model that unified all mainly used measures, concepts, and terms in a Thai study. The Public Speaking Class Anxiety Scale in English comprises four dimensions of English speech anxiety; Anticipated Anxious Behaviours in Speaking English, Comfort in Speaking English, Communication Apprehension, and Test Anxiety (Yaikhong \& Usaha, 2012). Yaikhong and Usaha (2012) identified commonalities in the various famous instruments of foreign language anxiety and combined these models into a single English-speaking anxiety measurement model.

For the reasons, speech anxiety can be most prevalent in situations associated with frequent student and instructors interaction, such as lab work in science classes (Seiler et al., 1978), small classroom settings (McCroskey, 1977), and university education (Boohar \& Seiler, 1982). Hence, speaking anxiety is anticipated to be more related to students' grades in those situations. Therefore, it is important to test this model in contrasting classroom environments.

Young (1991) recommended that the relationships between academic grades and anxiety types should be probed because English speech anxiety has different dimensions. Therefore, it is needed to examine which dimension impacts students' grades and to which extent. Although previous studies have highlighted the relationships of various academic programs with students' academic performance, there is a need to explore proportions of variance in these differences explainable by the students' speech anxiety in an English medium instructional environment. In an English medium of instruction, students' medium of instruction and examination is English, but English is not their first or second language; instead, it is a foreign language (Macaro et al., 2017). Furthermore, it is worthwhile to explore whether it is possible to explain students' anxiety dimension differences regarding the subject they are studying and how these different dimensions of speaking anxiety impact students' academic grades.

Pakistan has English medium instruction at the university level. Therefore this study aimed to discover students' speaking anxiety links to various academic fields offered to students. Consequently, the conceptual framework shown in Figure 1 depicts that the current study explores the relationships of different academic areas with students' English speech anxiety and their academic performance. 


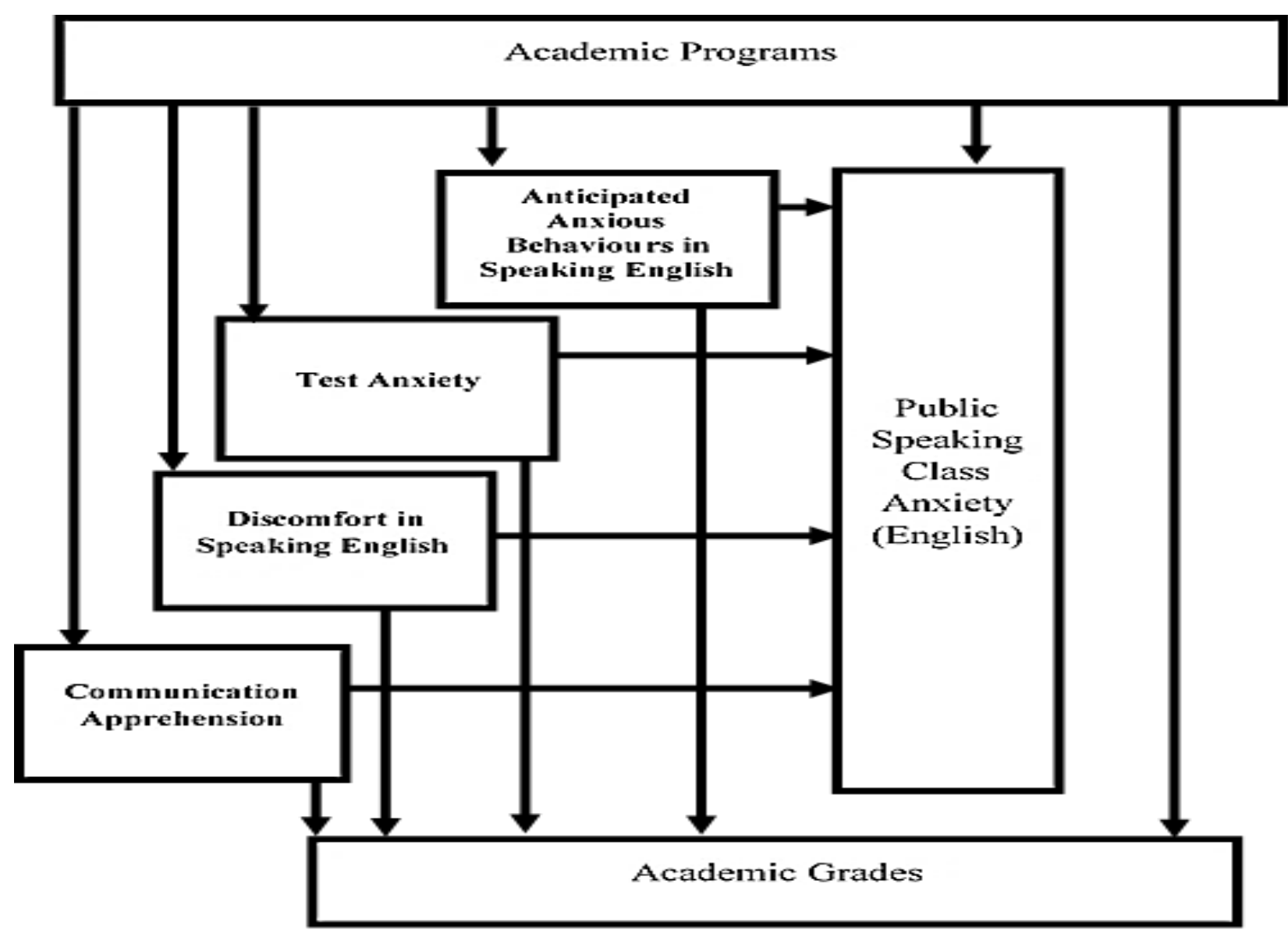

\section{Figure 1: Conceptual Framework}

Based on the above conceptual basis, the study has the following objectives:

1. To explore the impact of different fields of study on students' English speech anxiety.

2. To discover the impact of different dimensions of speech anxiety on students' academic performance.

3. To identify the impact of students' academic programs on their academic performance.

4. To identify the total effect of academic programs on students' academic performance, including students' English speaking anxieties.

5. To find the mediation role of different speech anxieties in determining the impact of academic programs on students' academic performance.

The researcher formulated the following postulates to fulfil the pre-defined objectives of the study:

1. There will be no significant impact of different fields of study on students' English speech anxiety.

2. There will be no significant impact of different dimensions of speech anxiety on students' academic performance.

3. There will be no significant impact of students' academic programs on their academic performance.

4. There will be no significant total effect of academic programs on students' academic performance, including students' English speaking anxieties.

5. There will be no significant mediation role of different speech anxieties in determining the impact of academic programs on students' academic performance. 


\section{Review of Economics and Development Studies, Vol. 7 (4) 2021, 501 - 514}

\section{Method}

\subsection{Sample}

The study sample was 534 undergraduate and postgraduate students of the Bahawalnagar campus of the Islamia University of Bahawalpur. Researchers used the convenience sampling technique (Gay et al., 2012) in this study. The students available and volunteered to respond were counted as the study sample. The sample comprised 48 (8.98\%) social science, 294 (55.05\%) science, 27 (5\%) computer science and information technology, and 165 (31.46\%) English literature students in the sample. The sample size was considered sufficient because it was above the minimum rule of 10 times per arrow in the model (Hair et al., 2017) (Figure 2).

\subsection{Data Collection}

The researchers used EFL Public Speaking Class Anxiety Scale (PSCAS) (Yaikhong \& Usaha, 2012) to measure students' English language speech anxiety. This scale was developed by Yaikhong and Usaha (2012) by combining different items from the most prevalent English language anxiety scales. The selected items of PSCAS in this study measured four dimensions: Anticipated Anxious Behaviours in Speaking English, Communication Apprehension, Discomfort in Speaking English, Test Anxiety. The PSCAS final version of Yaikhong and Usaha (2012) consisted of 17 items. These 17 items were found relevant and appropriate in the Thai context. However, there were 14 items found suitable in the Pakistani context. The dimensions of Anticipated Anxious Behaviours in Speaking English and Communication Apprehension consisted of four items each, whereas Discomfort in Speaking English and Test anxiety dimensions consisted of three items each. The researchers reversed the coding of 03 Items of Comfort in Speaking English for changing these into discomfort in speaking English to make this dimension cohesive with the other three dimensions that imply speaking anxiety. In this way, 14 items were found valid and reliable in this study (Table No.1 and Table No. 2). The students provided their responses to each statement on a five-point scale of agreement ranging from strongly disagree $=1$, disagree $=2$, Neutral $=3$, Agree $=4$, Strangely Agree $=5$. The academic department was coded dummy variables. Each department has two values, o and 1.

\subsection{Data Analysis}

The researchers used the structural equation modeling approach to identify the significance and strength of anticipated direct and total effects. The structural equation modeling partial least squares approach was chosen because of its robustness to small sample size and normality issues (Hair et al., 2019). Furthermore, the PLS-SEM is suitable for exploratory research (Hair et al., 2017) because the objectives and hypotheses of the study are exploratory. The Smartpls2 software assisted in PLS-SEM modeling.

\section{Results}

\subsection{Measurement Model Analysis}

Table No. 1 and Figure 2 depict different measurement model associated parameters. The values of Average variance extracted (AVE) of four dimensions of English speaking anxiety are above o.50. it means that the four dimensions of public speaking anxiety have adequate convergent validity (Hair et al., 2019). Furthermore, the composite reliability Rho and internal consistency measure Cronbach's Alpha values are above 0.70 . These values reflect the composite reliability and internal consistency reliabilities of dimensions of English speaking anxiety within an acceptable range (Hair et al., 2019). Furthermore, all item loadings on the supposed dimensions of Speech anxiety are significant and above 0.50 because the loading of an item on the latent variable should be above 0.50 to consider its loading significant (Hair et al., 2014). 
Review of Economics and Development Studies, Vol. 7 (4) 2021, 501 - 514

\begin{tabular}{|c|c|c|c|c|c|}
\hline \multicolumn{6}{|c|}{$\begin{array}{l}\text { Table No. } 1 \\
\text { Loadings, Validity and Reliability }\end{array}$} \\
\hline Measure & Items & Loadings & AVE & $\begin{array}{l}\text { Composite } \\
\text { Reliability }\end{array}$ & Cronbach's Alpha \\
\hline \multirow{4}{*}{$\begin{array}{l}\text { Anticipated } \\
\text { Behaviors in Speaking } \\
\text { English }\end{array}$} & PSCAS_2 & $0.7308^{* * *}$ & \multirow{4}{*}{0.5742} & \multirow{4}{*}{0.8435} & \multirow{4}{*}{0.7576} \\
\hline & PSCAS_3 & $0.7359^{* * *}$ & & & \\
\hline & PSCAS_5 & $0.7986 * * *$ & & & \\
\hline & PSCAS_15 & $0.7638 * * *$ & & & \\
\hline \multirow{3}{*}{$\begin{array}{l}\text { Discomfort in Speaking } \\
\text { English }\end{array}$} & PSCAS_4R & $0.8873^{* * *}$ & \multirow{3}{*}{0.6415} & \multirow{3}{*}{0.8421} & \multirow{3}{*}{0.7209} \\
\hline & $\begin{array}{l}\text { PSCAS_10 } \\
\mathrm{R}\end{array}$ & $0.7704^{* * *}$ & & & \\
\hline & $\begin{array}{l}\text { PSCAS_12 } \\
\mathrm{R}\end{array}$ & $0.7373^{* * *}$ & & & \\
\hline \multirow{4}{*}{$\begin{array}{l}\text { Communication } \\
\text { Apprehension }\end{array}$} & PSCAS_9 & $0.7331 * * *$ & \multirow{4}{*}{0.5751} & \multirow{4}{*}{0.8438} & \multirow{4}{*}{0.7581} \\
\hline & PSCAS_11 & $0.7893^{* * *}$ & & & \\
\hline & PSCAS_13 & $0.7933^{* * *}$ & & & \\
\hline & PSCAS_14 & $0.7146^{* * *}$ & & & \\
\hline \multirow[t]{3}{*}{ Test Anxiety } & PSCAS_1 & $\begin{array}{l}0.8906^{* *} \\
*\end{array}$ & \multirow{3}{*}{$\begin{array}{l}0.606 \\
9\end{array}$} & \multirow{3}{*}{0.82} & \multirow{3}{*}{0.7174} \\
\hline & PSCAS_7 & $0.7808 * *$ & & & \\
\hline & PSCAS_17 & $0.6465^{* *}$ & & & \\
\hline
\end{tabular}

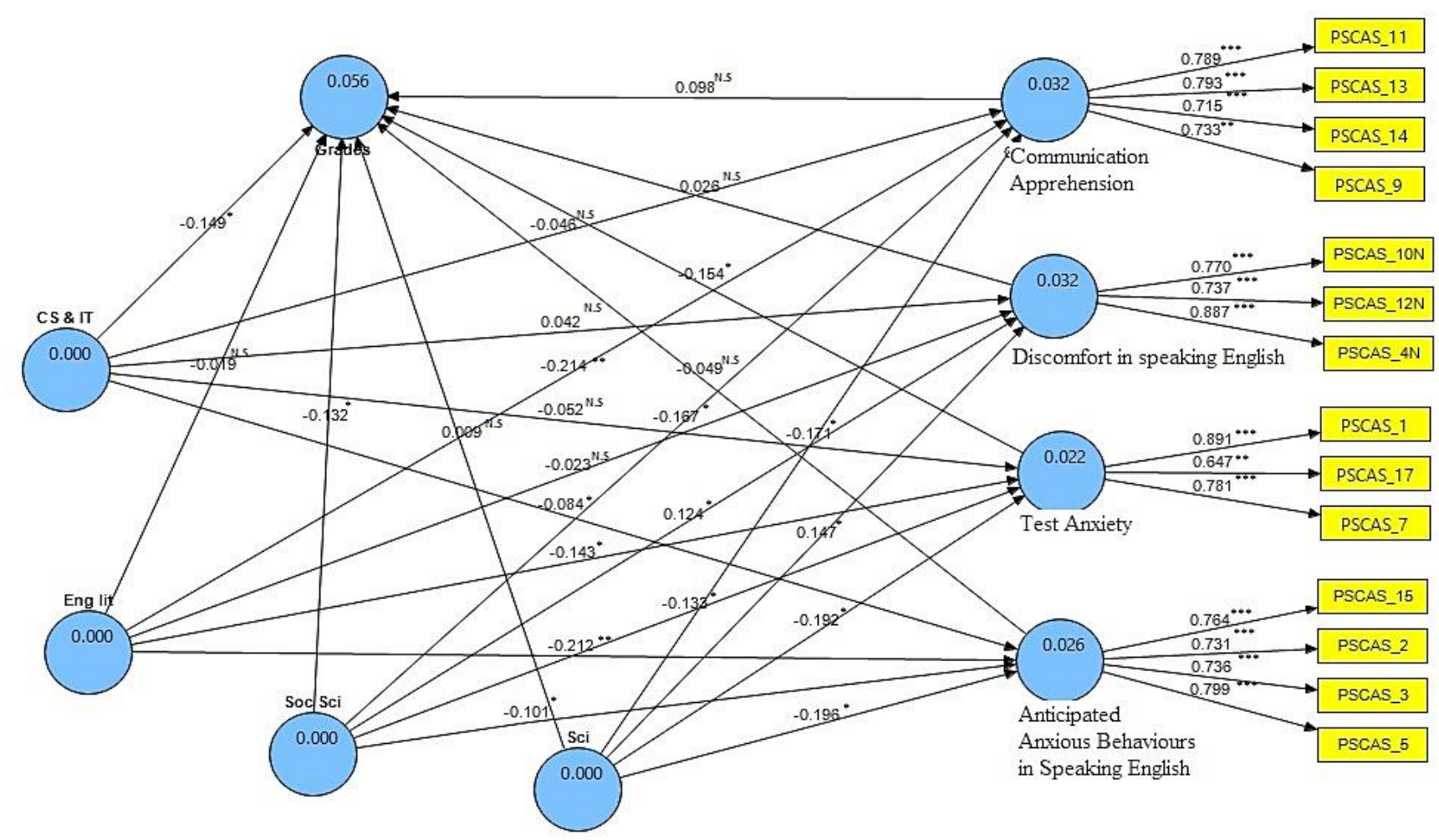

Figure No. 2: First and Second Stage SEM Analysis 
Review of Economics and Development Studies, Vol. 7 (4) 2021, 501 - 514

The measure model results show that the four latent variables in the model, Anticipated Anxious Behaviours in Speaking English, Communication Apprehension, Discomfort in Speaking English, and Test Anxiety have the discriminant validity (Table No. 2). The square root of AVEs of these latent variables is above their interrelationships with other latent variables in the model (Table No. 2). Hence the data in Table No. 2 affirm that latent variables in the model have discriminant validity (Henseler et al., 2016).

\begin{tabular}{|l|l|l|l|l|l|}
\hline \multicolumn{5}{|l|}{ Table No. 2} \\
\hline \multicolumn{2}{|l|}{ Discriminant Validity Latent Variables (Fornell-Larcker Criterion) } \\
\hline Sr. No & Latent Variables & $\mathbf{1}$ & $\mathbf{2}$ & $\mathbf{3}$ & $\mathbf{4}$ \\
\hline 1 & Anticipated Anxious Behaviours in Speaking English & $\mathbf{0 . 7 5 8}$ & & & \\
\hline 2 & Communication Apprehension & 0.737 & $\mathbf{0 . 7 5 8}$ & & \\
\hline 3 & Discomfort in Speaking English & 0.047 & -0.019 & $\mathbf{0 . 8 0 1}$ & \\
\hline 4 & Test Anxiety & 0.688 & 0.675 & -0.013 & $\mathbf{0 . 7 7 9}$ \\
\hline
\end{tabular}

\subsection{Structural Model Analysis}

Table No. 3 shows that different academic programs impact students' English speech anxiety. Various educational programs impart impacts on students' academic grades. The academic programs included in the study, the social science, English literature, Physical sciences, computer science, and information technology, were associated with a significant decrease in students' Anticipated Anxious Behaviours in Speaking English. However, there are differences in the magnitude of these academic programs' negative impact on Anticipated Anxious Behaviours in Speaking English. The computer science and information technology program has the most negligible adverse effect on Anticipated Anxious Behaviours in Speaking English.

In comparison, the English literature department has the highest negative impact on students' Anticipated Anxious Behaviours in Speaking English. Unexpectedly, Physical science impact was the second higher negative impact on Anticipated Anxious Behaviours in Speaking English. It is worth mentioning that students with higher academic backgrounds opt for sciences. The negative impact of social sciences on Anticipated Anxious Behaviours in Speaking English was half compared to the negative effects of the physical sciences and English literature departments on students' Anticipated Anxious Behaviours in Speaking English.

The academic programs significantly impacted students' comfort in Speaking English. The academic programs of social science and physical sciences positively and substantially impact students' discomfort in speaking English. The impact of English literature on discomfort in Speaking English was negative but not significant. These impacts are almost in the anticipated directions. 


\begin{tabular}{|c|c|c|c|}
\hline \multicolumn{4}{|l|}{ Table No. 3} \\
\hline \multicolumn{4}{|l|}{ Direct Effects } \\
\hline Path & $\begin{array}{l}\text { Original } \\
\text { Sample (O) }\end{array}$ & $\begin{array}{l}\text { Sample } \\
\text { Mean (M) }\end{array}$ & T Statistics \\
\hline \multicolumn{4}{|c|}{ Academic Programs -> Anticipated Anxious Behaviours in Speaking English } \\
\hline $\begin{array}{l}\text { Social Sciences -> Anticipated Anxious Behaviours in } \\
\text { Speaking English }\end{array}$ & -0.1012 & -0.1035 & $2.2259^{*}$ \\
\hline $\begin{array}{l}\text { English Literature -> Anticipated Anxious Behaviours } \\
\text { in Speaking English }\end{array}$ & -0.2121 & -0.2178 & $4.1778^{* *}$ \\
\hline $\begin{array}{l}\text { Physical Sciences -> Anticipated Anxious Behaviours } \\
\text { in Speaking English }\end{array}$ & -0.1958 & -0.2007 & $3.6389 *$ \\
\hline $\begin{array}{l}\text { Computer Sciences \& Information Technology -> } \\
\text { Anticipated Anxious Behaviours in Speaking English }\end{array}$ & -0.0836 & -0.0829 & $2.2744^{*}$ \\
\hline \multicolumn{4}{|l|}{$\begin{array}{l}\text { Academic Programs } \rightarrow \text { Discomfort in Speaking } \\
\text { English }\end{array}$} \\
\hline Social Sciences -> Discomfort in Speaking English & 0.1244 & 0.126 & $2.5996^{*}$ \\
\hline English Literature -> Discomfort in Speaking English & -0.0229 & -0.0237 & $0.4405^{\text {N.S }}$ \\
\hline Physical Sciences -> Discomfort in Speaking English & 0.147 & 0.1482 & $2.769^{*}$ \\
\hline $\begin{array}{l}\text { Computer Sciences \& Information Technology } \quad-> \\
\text { Discomfort in Speaking English }\end{array}$ & 0.0424 & 0.0425 & $1.0085^{\text {N.S }}$ \\
\hline \multicolumn{4}{|l|}{ Academic Programs -> Test Anxiety } \\
\hline Social Sciences -> Test Anxiety & -0.1332 & -0.134 & $3.0368 *$ \\
\hline English Literature -> Test Anxiety & -0.1434 & -0.1474 & $2.6983^{*}$ \\
\hline Physical Sciences -> Test Anxiety & -0.1918 & -0.1949 & $3.6787^{*}$ \\
\hline $\begin{array}{l}\text { Computer Sciences \& Information Technology -> Test } \\
\text { Anxiety }\end{array}$ & -0.0518 & -0.0518 & $1.13^{\text {N.S }}$ \\
\hline $\begin{array}{l}\text { Academy Programs } \quad->\quad \text { Communication } \\
\text { Apprehension }\end{array}$ & & & \\
\hline Social Sciences -> Communication Apprehension & -0.1669 & -0.1717 & $3.6684^{*}$ \\
\hline English Literature -> Communication Apprehension & -0.2139 & -0.2183 & $4 \cdot 3293^{* *}$ \\
\hline Physical Sciences -> Communication Apprehension & -0.1709 & -0.1743 & $3.4091^{*}$ \\
\hline $\begin{array}{l}\text { Computer Sciences \& Information Technology } \quad-> \\
\text { Communication Apprehension }\end{array}$ & -0.0457 & -0.0453 & $1.1368^{\mathrm{N} . \mathrm{S}}$ \\
\hline \multicolumn{4}{|l|}{$\begin{array}{l}\text { Public Speaking Class Anxiety Scale Dimension and } \\
\text { Grades }\end{array}$} \\
\hline $\begin{array}{l}\text { Anticipated Anxious Behaviours in Speaking English - } \\
>\text { Grades }\end{array}$ & -0.0494 & -0.053 & $0.8288^{\mathrm{N} . \mathrm{S}}$ \\
\hline Discomfort in Speaking English -> Grades & 0.0261 & 0.027 & $0.7104^{N . S}$ \\
\hline Test Anxiety -> Grades & -0.1537 & -0.1461 & $2.5849^{*}$ \\
\hline
\end{tabular}


Review of Economics and Development Studies, Vol. 7 (4) 2021, 501 - 514

\begin{tabular}{|c|c|c|c|}
\hline Communication Apprehension -> Grades & 0.0981 & 0.0928 & $1.6287^{\mathrm{N} . \mathrm{S}}$ \\
\hline \multicolumn{4}{|l|}{ Academic Program and Grades } \\
\hline Social Sciences -> Grades & -0.1318 & -0.1333 & $2.9743^{*}$ \\
\hline English Literature -> Grades & -0.0188 & -0.0207 & $0.3919^{\text {N.S }}$ \\
\hline Physical Sciences -> Grades & 0.0092 & 0.0077 & $0.1655^{\text {N.S }}$ \\
\hline $\begin{array}{l}\text { Computer Sciences \& Information Technology -> } \\
\text { Grades }\end{array}$ & -0.1488 & -0.1482 & $3.2282^{*}$ \\
\hline
\end{tabular}

There was a significant impact of different academic programs on students' Test Anxiety. Academic programs of physical sciences, English literature, and social sciences negatively impact students' English speech test anxiety. In comparison, the impact of computer science and information technology on English-speaking test anxiety was also negative but insignificant. Likewise, the effects of academic programs of English, physical sciences, and social sciences are adverse and significant. All these students are afraid of speaking English in class and have English communication apprehension. In the case of different dimensions of English speech anxiety on students' academic grades, only the dimension of Test anxiety has a significant negative impact on students' grades. In comparison, the academic programs of social sciences, computer sciences, and information technology significantly negatively affect students' academic grades. The other two academic programs have insignificant impacts.

Table No. 4 shows the total effects of academic programs on students' grades. There are significant total effects of academic programs on academic grades via speech anxiety dimensions. It means that students' speech anxiety can intervene in relationships between students' academic grades and academic programs.

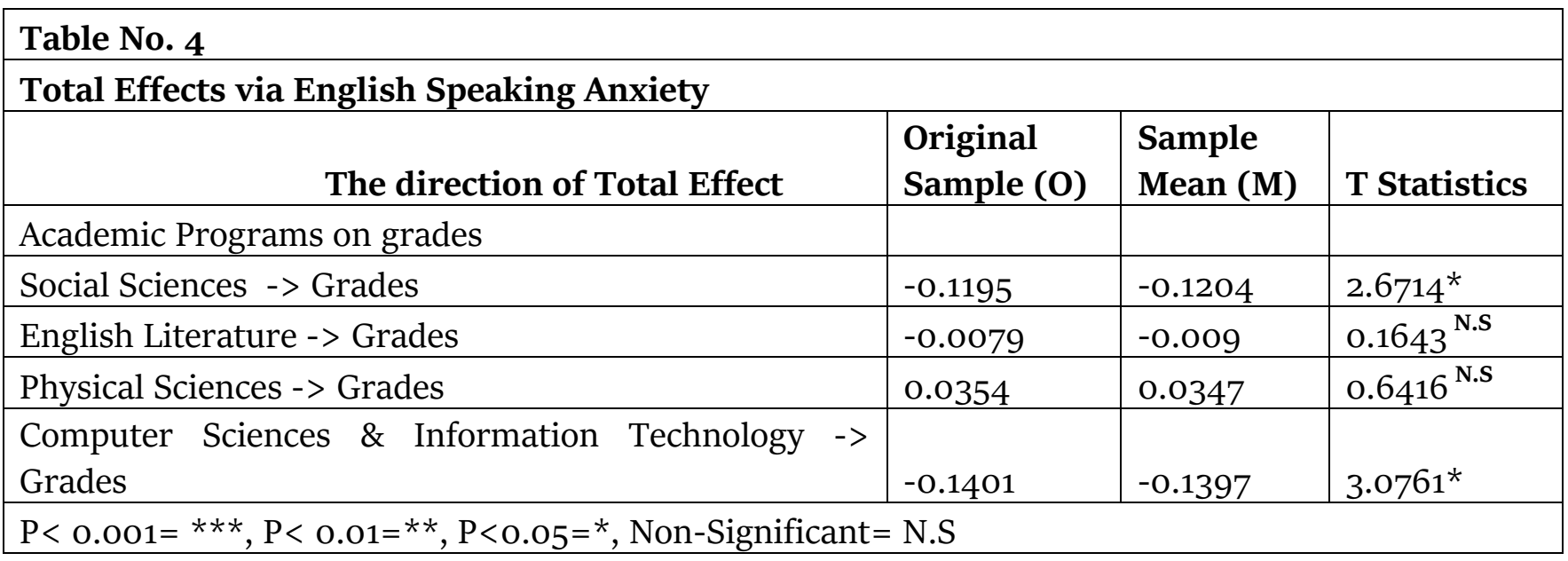

Table No. 5 shows the mediation role of dimensions of speech anxiety on students' academic grades. Test anxiety was the only dimension that had a significant negative impact on students' academic grades. In comparison, the academic programs of social sciences and computer science have substantial adverse effects on students' grades. However, only the social sciences academic program has a significant negative impact on test anxiety, whereas the computer science program has an insignificant negative impact. The ratios of total effect and total indirect effect show that the impact of 
the social sciences academic field on academic grades is significantly partially mediated by the students' English speech test anxiety.

\begin{tabular}{|c|c|c|c|c|c|}
\hline \multicolumn{6}{|l|}{ Summary of Mediation Results } \\
\hline \multirow[b]{2}{*}{ Hypothesis } & \multirow[b]{2}{*}{$\begin{array}{l}\text { Direct effect } \\
\text { Social } \\
\text { Sciences on } \\
\text { Academic } \\
\text { Grades } \\
\end{array}$} & \multicolumn{2}{|c|}{ Indirect Effect } & \multirow[b]{2}{*}{$\begin{array}{l}\text { Total } \\
\text { Effect }\end{array}$} & \multirow[b]{2}{*}{$\begin{array}{l}\text { VAF } \\
\text { Decisio } \\
\mathbf{n}\end{array}$} \\
\hline & & $\begin{array}{l}\text { Sciences } \\
\text { on Test } \\
\text { Anxiety }\end{array}$ & $\begin{array}{l}\text { Test } \\
\text { Anxiety on } \\
\text { Grades }\end{array}$ & & \\
\hline $\begin{array}{l}\text { Mediation English Speech Test } \\
\text { Anxiety in the impact of academic } \\
\text { programs on students' academic } \\
\text { performance }\end{array}$ & -0.1318 & -0.1332 & -0.1537 & -0.1113 & $18.41 \%$ \\
\hline
\end{tabular}

Table 6 shows that the hypothesized structural model explains $2.6 \%$ variance in Anticipated Anxious Behaviours in Speaking English, 3.2\% variance in Communication Apprehension, $3.1 \%$ variances in Discomfort in Speaking English, and 2.1\% variance in test anxiety. The structural model explains a $5 \cdot 5 \%$ variance in students' academic grades.

\begin{tabular}{|l|l|}
\hline Table No. 6 & \\
\hline Variance Function of Model & \\
\hline Variable & R Square \\
\hline Anticipated Anxious Behaviours in Speaking English & 0.0263 \\
\hline Communication Apprehension & 0.032 \\
\hline Discomfort in Speaking English & 0.0316 \\
\hline Test Anxiety & 0.0217 \\
\hline Grades & 0.0559 \\
\hline
\end{tabular}

\section{Discussion}

The study found that there is a likelihood that students' English speech anxiety will differ with regard to programs of study. It is found that anticipated Anxious Behaviours in Speaking English were least negatively related in computer science and information technology students, whereas it was most negatively associated with English literature and physical sciences students. The English literature students usually communicate with teachers in English. Therefore, the Anticipated Anxious Behaviours in Speaking English was most negatively related to this academic program. Science students generally communicate in English with teachers during regular class and practical work. Therefore, this practice reduced their Anticipated Anxious Behaviours in Speaking English. Whereas social sciences students are not having dialogue like the English literature and science class students, there is a relatively less negative association with Anticipated Anxious Behaviours in Speaking English. 


\section{Review of Economics and Development Studies, Vol. 7 (4) 2021, 501 - 514}

The study found that social sciences and physical science programs positively associate with the discomfort in speaking English. It is in line with the literature that students of these programs most of the time read the content specific to the subject, and their general speaking skills are not improved. Therefore, they usually feel uncomfortable when explaining things being read or learned.

The fear of negative evaluation and test anxiety were least negatively associated with social sciences and most negatively related to physical science students. It means that social science students are the most to have speech test anxiety. The English communication apprehension was most negatively associated with English literature and physical science students and least negatively related to social sciences. Overall it seems that students of social sciences are the students who can have the most apparent English-speaking anxieties as compared to English literature and Physical sciences students. Although the anticipated anxious English speaking behaviour, communication apprehension, and speaking discomfort seem unrelated to academic grades, The English speech test anxiety was the only one that appeared relevant to students' academic grades. It is in line with the literature because general anxiety is also related to lower academic grades (Siebers, 2015; Vitasaria et al., 2010). The same general anxiety is reflected in students' speech anxiety. Therefore, it appears that English speech anxiety components, communication apprehension, discomfort in speaking English, and anticipated anxious English speaking behaviour have some different roots and implications than the test anxiety element of English speech anxiety. Here general anxiety seems reflected in English-speaking test anxiety. This finding corroborates earlier findings that high levels of anxiety in students are associated with their low academic grades (Siebers, 2015; Vitasaria et al., 2010)

In this way, the test anxiety element seems to mediate the impact of the social sciences program of study on students' academic performance. The other dimensions do not lead to significant relationships to academic grades. Therefore the remaining three dimensions do not significantly mediate the relationships between academic programs and academic grades.

This study corroborates that subject nature and classroom practices impact students' anxiety levels. The students' academic performance or academic grades vary with regard to their academic programs. The relationships of social science are less negative with different dimensions of English language anxiety, and consequently, it has a negative association with students' grades. The relationship of social sciences with grades is mediated by test anxiety. These affirm the prior findings that English speech anxiety is negatively associated with students' academic performance (Amiri \& Ghonsooly, 2015).

Furthermore, it is reiterated that students' speech anxiety can mediate the relationship between students' academic programs and academic grades. The social sciences students receive education in partial English medium instruction. Therefore, they might have high speech anxiety (Chou, 2018).

The science students are optimistic and enthusiastic about the English medium of instruction (Al-Masheikhi et al., 2014). Therefore, the lesser levels of anxiety than social sciences students in speech anxiety are understandable. Another factor of high anxiety in social sciences students is that most of the subjects offered to social sciences' students before entering into university education in Grades: 10-12 are in Urdu. Whereas the subjects offered to science students are offered in English. The English background of science students, compared to social science students, assist science students in overcoming their speech anxiety. 


\section{Review of Economics and Development Studies, Vol. 7 (4) 2021, 501 - 514}

\section{Conclusion}

The impact and direction of different dimensions of English speaking anxiety depend on the courses and academic programs the students study. However, the test-anxiety element in English speaking anxiety, roots in general test anxiety, might lead to low academic grades in university students in an English medium instruction system. The students in the academic program of social sciences most probably have higher speech or English language anxiety due to non-English medium educational background.

\section{Recommendations}

It is recommended that teachers in English medium instruction systems should recognize English speech anxiety among students. Universities should provide training to teachers for teaching at universities in Pakistan and counselling students if they have speech anxiety. Clinical support should be provided to help out those students who have higher levels of English speech anxiety. It is of utmost requirement because the prevalence of this psychological mental health situation can lead to further psychological and physical illness of the students.

\section{References}

Aida, Y. (1994). Examination of Horwitz, Horwitz, and Cope's Construct of Foreign Language Anxiety: The Case of Students of Japanese. The Modern Language Journal, 78(2), 155-168. doi:10.2307/329005

Al-Masheikhi, F., Al-Mahrooqi, R., \& Denman, C. J. (2014). Investigating college of science student attitudes towards using English as a medium of instruction. Paper presented at the 2014 WEI international academic conference, New Orleans, USA. Retrieved from http://www.westeastinstitute.com/wp-content/uploads/2014/11/Eiman-RahmaChristopher.pdf

American Psychological Association. (2020). public-speaking anxiety. Retrieved from https://dictionary.apa.org/public-speaking-anxiety

Amiri, M., \& Ghonsooly, B. (2015). The Relationship between English Learning Anxiety and the Students' Achievement on Examinations. Journal of Language Teaching and Research, 6(4), 855-865. doi:http://dx.doi.org/10.17507/jltr.0604.20

Boohar, R. K., \& Seiler, W. J. (1982). Speech communication anxiety: an impediment to academic achievement in the university classroom. The Journal of Classroom Interaction, 18(1), 2327. Retrieved from http://www.jstor.org/stable/23884749

Chou, M.-H. (2018). Speaking Anxiety and Strategy Use for Learning English as a Foreign Language in Full and Partial English-Medium Instruction Contexts. TESOL Quarterly, 52(3), 611-633. doi:https://doi.org/10.1002/tesq.455

D'Esposito, S. E., Blake, J., \& Riccio, C. A. (2011). Adolescents' Vulnerability to Peer Victimization: Interpersonal and Intrapersonal Predictors. Professional School Counseling, 14(5), 299309. Retrieved from http://www.jstor.org/stable/23801080

Foyewa, R. A. (2015). English: the international language of science and technology. International Journal of English Language and Linguistics Research, 3(5), 34-41. Retrieved from https://www.eajournals.org/wp-content/uploads/English-The-International-Language-ofScience-and-Technology.pdf

Fremouw, W. J., \& Breitenstein, J. L. (1990). Speech Anxiety. In L. H (Ed.), Handbook of Social and Evaluation Anxiety (pp. 455-474). Boston: Springer.

Gardner, R. C., \& MacIntyre, P. D. (1993). On the Measurement of Affective Variables in Second Language Learning. Language Learning, 43(2), 157-194. doi:https://doi.org/10.1111/j.1467- 


\section{Review of Economics and Development Studies, Vol. 7 (4) 2021, 501 - 514}

1770.1992.tboo714.X

Gay, L. R., E., M. G., \& Airasian, P. (2012). In C. Robb (Ed.), Educational research : competencies for analysis and applications (10th ed.). New Jersey: Pearson Education.

Gordin, M. D. (2015) Scientific Babel, How Science Was Done Before and After Global English. Chicago: University of Chicago Press.

Hair, J., F., Hult, G., Tomas, M., Ringle, C., M., \& Sarstedt, M. (2014). Primer on Partial Least Squares Structural Equation Modeling (PLS-SEM). California, USA: SAGE Publications, Inc.

Hair, J., F., Hult, G., Tomas, M., Ringle, C., M., \& Sarstedt, M. (2017). Primer on Partial Least Squares Structural Equation Modeling (PLS-SEM). California, USA: SAGE Publications, Inc.

Hair, J. F., Risher, J. J., Sarstedt, M., \& Ringle, C. M. (2019). When to use and how to report the results of PLS-SEM. European Business Review, 31(1), 2-24. doi:10.1108/EBR-11-2018-0203

Henseler, J., Hubona, G., \& Ray, P. A. (2016). Using PLS path modeling in new technology research:updated guidelines. Industrial Management \& Data Systems, 116(1), 2-10. doi:DOI 10.1108/IMDS-09-2015-0382

Hinkel, E. (2006). Current Perspectives on Teaching the Four Skills. TESOL Quarterly, 40(1), 109131. doi:10.2307/40264513

Horwitz, E. K., Horwitz, M. B., \& Cope, J. (1986). Foreign Language Classroom Anxiety. The Modern Language Journal, 70(2), 125-132. doi:10.2307/327317

Hughes, A. A., Lourea-Waddell, B., \& Kendall, P. C. (2008). Somatic Complaints in Children with Anxiety Disorders and their Unique Prediction of Poorer Academic Performance. Child Psychiatry and Human Development, 39(2), 211-220. doi:10.1007/s10578-007-0082-5

Macaro, E., Curle, S., Pun, J., An, J., \& Dearden, J. (2017). A systematic review of English medium instruction in higher education. Language Teaching, 51(1), 36-76. doi:10.1017/So261444817000350

McCroskey, J. C. (1977). Classroom consequences of communication apprehension. Communication Education, 26(1), 27-33. doi:10.1080/03634527709378196

Miller, M. T., \& Edmunds, N. A. (1992). Communication Apprehension and Academic Achievement Implications for Industrial Education Students. The Journal of Epsilon Pi Tau, 18(1), 33-37. Retrieved from http://www.jstor.org/stable/43603583

Nunan, D. (2003). The Impact of English as a Global Language on Educational Policies and Practices in the Asia-Pacific Region. TESOL Quarterly, 37(4), 589-613. doi:10.2307/3588214

Pappamihiel, N. E. (2002). English as a Second Language Students and English Language Anxiety: Issues in the Mainstream Classroom. Research in the Teaching of English, 36(3), 327-355. Retrieved from http://www.jstor.org/stable/40171530

Ramírez-Castañeda, V. (2020). Disadvantages in preparing and publishing scientific papers caused by the dominance of the English language in science: The case of Colombian researchers in biological sciences. PLoS ONE, 15(9), e0238372. doi:10.1371/journal.pone.0238372

Rapee, R. M., Schniering, C. A., \& Hudson, J. L. (2009). Anxiety disorders during childhood and adolescence: origins and treatment. Annu Rev Clin Psychol, 5, 311-341. doi:10.1146/annurev.clinpsy.032408.153628

Schneider, E. (2014). The fate of a global language. The World Today, 70(6), 16-18. Retrieved from http://www.jstor.org/stable/45048684

Seiler, W. J., Boohar, R. K., \& Garrison, J. P. (1978). Speech Anxiety and Student Learning. Journal of College Science Teaching, 7(4), 223-226. Retrieved from http://www.jstor.org/stable/42988062

Shohamy, E. (2014). The Weight of English in Global Perspective: The Role of English in Israel. Review of Research in Education, 38, 273-289. Retrieved from http://www.jstor.org/stable/43284070 
Siebers, W. M. (2015). The relationship between math anxiety and student achievement of middle school students. (Doctor of Philosophy), Colorado State University, Colorado. Retrieved from

https://mountainscholar.org/bitstream/handle/10217/166940/Siebers_colostate_o053A_12 903.pdf

Vitasaria, P., Abdul Wahabb, M. N., Othmanc, A., Herawand, T., \& Sinnadurai, S. K. (2010). The Relationship between Study Anxiety and Academic Performance among Engineering Students. Procedia Social and Behavioral Sciences, 8, 490-497. doi:doi:10.1016/j.sbspro.2010.12.067

Yaikhong, K., \& Usaha, S. (2012). A Measure of EFL Public Speaking Class Anxiety: Scale Development and Preliminary Validation and Reliability. English Language Teach, 5(12), 23-35. doi:doi:10.5539/elt.v5n12p23

Young, D. J. (1991). Creating a Low-Anxiety Classroom Environment: What Does Language Anxiety Research Suggest? The Modern Language Journal, 75(4), 426-439. doi:10.2307/329492 